Global Conferences Series:

Social Sciences, Education and Humanities (GCSSSEH), Volume 3, 2019

The $1^{\text {st }}$ International Conference on Education, Social Sciences and Humanities

DOI: https://doi.org/10.326/hum0202

\title{
Developing Ability to Think Students in Primary School Through Questioning Skills
}

\section{Marien Pinontoan ${ }^{1}$, Mersty Rindengan $^{2}$}

1,2 Universitas Negeri Manado, Tondano, Indonesia.

(*) $\bowtie$ marienpinontoan59@gmail.com

\begin{abstract}
This study aims to determine the ability to think through the skills of asking fifth grade students of SD GMIM III Tomohon. The research method used is classroom action research, because the problem is in classroom learning that requires direct completion. This research was conducted with 3 cycle rounds. The findings of this study indicate that in the first round there were still many weaknesses in class teachers who used questioning skills in the learning process, but before the second, third round, guidance was held to improve the ability of teachers to use classroom questioning skills, impact learning or very positive towards improving thinking skills of elementary school students in fifth grade. So questioning skills are one of the teaching skills that can improve students' thinking skills.
\end{abstract}

Keywords : Ability to think, questioning skill, Primary School student

\section{Introduction}

The skill of asking as a basic teaching skill must be seen as a teaching skill that can improve students' thinking skills. As Dewey (in an article) argued that the right skills and encouraging students' thinking skills were questions asked. Gary D. Borich (1988: 235) suggests that questions are practical guidance for students to think both inductively and deductively or questions function to improve and encourage students to think.

Asking as teaching skills is the heart of teaching that plays a vital role in the teaching and learning process. Cahrles De Garmo (James M. Cooper, 1986: 87) argues that "good questioning is a reflection of good teaching, asking is better than the art of teaching,

Copyright () 2019, the Authors. Published by Redwhite Press.

Page | 91

This is an open access article under the CC BY-NC license

(http://creativecommons.org/licenses/by-nc/4.0). 
asking questions to help children get ideas quickly and stimulate thinking, and encourage children to do something action ".

In the classroom learning process, questions play a very vital role, and since 2000 (since Socrates) questions have been used as teaching methods. Since then the ability to give questions to students in the teaching and learning process is one of the necessary qualifications for teachers in successful teaching. John Dewey also said that the question is one of the teaching approaches that encourages students to carry out thinking, conduct critical assessments, gather information, and in the learning process questions play a role in appropriately assessing the teaching strategies used and the material being taught.

Packard (2009: 59) suggests the findings of his research that "The use of questions in the learning process can increase stimulus in the classroom. $80 \%$ of teachers who use questioning skills in teaching suggest that if the question is used well by the teacher in teaching, it will improve students' thinking skills from cognitive thinking skills to applicative thinking, analysis, synthesis, evaluative or produce new thoughts that can solve problems.

The way of thinking is determined by various factors. A similar problem, might lead to different solutions for each person, so the results might be different. As for the factors that can influence the way of thinking, among others, how someone sees or understands the problem, the situation that is being experienced by someone and the external situation faced, the experiences of that person, and how intelligent the person is.

Based on the findings in SD GMIM III Tomohon, if analyzed students' thinking skills are still relatively low. This is confirmed if the teacher uses difficult question sentences, students have not been able to understand the question. This condition is certainly interesting for further investigation. The mix of thinking referred to in this study is application thinking, analysis, synthesis and evaluation.

\section{Method}

This study uses Classroom Action Research (CAR). This type of research is used because the problem is that it is a daily problem in the learning process that requires direct resolution. The research procedure consists of planning, action, observation, and reflection. By doing three cycles. The population in this study were students in grade IV and V SD GMIM III Tomohon.

Data collection techniques in classroom action research include: document analysis and observation. The data obtained will be analysis and processed descriptively by using percentage techniques to see the tendency of activities that occur during learning 
activities take place. The success of this study refers to the level of mastery or understanding of students. A student can be said to have succeeded or completed in learning if mastery or understanding of the subject matter (student absorption) $\geq 70 \%$. While classical completeness is achieved if at least $85 \%$ of all students achieve mastery learning.

\section{Result and Discusion}

Of the 3 cycle rounds that have been implemented, the results obtained can be described as follows:

First cycle

Mastery of the ability to apply question skills in the learning process. In principle, it shows varying abilities and is still weak in its application, where: class teachers have shown symptoms of warmth and enthusiasm in asking questions to students. From the habits that need to be avoided by teachers in teaching, this study found: 1 class teacher has the habit of repeating his own questions, 2 people have the habit of repeating student answers. In its application, the mastery of the questioning skills by the classroom teacher, still varies as the findings of this study are difficult questions, the teacher should give a reference in the form of questions that contain relevant information with the answers expected by students, but have not been implemented. Giving thinking time to students in answering questions still varies. Providing guidance to students who have answered or incorrect answers to teacher questions, has not been done by classroom teachers in the learning process.

The ability to answer class IV students to a question still lies in the ability to think only of cognitive memory.

Second cycle

In the second cycle there has been a change towards improvement, namely: Mastery of classroom teachers applying questioning skills in the learning process, Teacher's skills in asking questions and stimulating students thinking in answering questions have increased, giving thought time has been done by the classroom teacher.

Students' ability to think has increased after the class teacher follows the training on questioning skills. The indications are: Of 24 fourth grade students; 23 students have been able to answer teacher questions and show symptoms of increased thinking ability. Of the 29 grade $\mathrm{V}$ students, 23 students have not been able to answer the teacher's questions correctly. Students have revealed high-level thinking skills that are able to answer application questions, analysis, synthesis and evaluation.

After analyzing, it turned out that in the second round there had been an increase in the ability of teachers to apply questioning skills in the learning process and to improve 
students' thinking skills in answering teacher questions. Weaknesses that arise from the parties are caused by the teacher personally not making careful preparation or because it is slow to absorb the results of coaching. While from the student side because students' intellectual abilities differ from one another.

Third cycle

Before the action / activity in the third round begins, it is also preceded by coaching. After reflection and analysis, the results are as follows:

1. Weakness in the case of submitting multiple questions and appointing students before asking, does not appear again in the third round.

2. The ability to think of Grade IV students in answering questions posed by teachers is still the same as in the second round.

Finally, from the three rounds of this research, it can be seen that to apply the questioning skills in the learning process and improve the thinking skills of elementary students in grades IV and V:

a. Having theoretical knowledge about skills in-depth inquiring as basic teaching skills.

b. Skilled in formulating questions that can stimulate students to think.

c. Mastering teaching material in the field of study and its application.

d. Questions according to type, type and classification cannot be applied equally at all grade levels in elementary school. As in the research, fourth grade students have not been able to think of giving answers to application questions, analysis, synthesis and evaluation.

e. In elementary school high level questions (advanced questions) are suitable or suitable to be applied to grades V and VI.

\section{Conclusion}

Based on the findings of this study, it can be concluded that:

1. The ability of teachers in grades IV and V of SD GMIM III Tomohon in applying questioning skills has undergone changes towards better achievement.

2. Students' thinking ability increases after the teacher applies the questioning skills well, to some of the learning that has been carried out.

3. Thinking ability of grade IV and V students of SD GMIM III Tomohon, according to their level of development and maturity cannot be forced.

\section{References}

Gary D. Borich, (2001), Effective Teaching Methods, Merill Publishing Company, Columbus Ohio. 
RedWhitepress Global Conferences Series: Social Sciences, Education and Humanities (GCSSSEH), Volume 3, 2019

John, I. Bola dan Raka Joni, (1985), Keterampilan Bertanya, P2LPTK, Dirjen Dikdasmen, Dikgu, Depdkbud, Jakarta.

James M. Cooper, (2000), Classroom Teaching Skills, $4^{\text {th }}$ ed. D. C. Heath and Company, USA.

Ngalim M. Purwanto, (2005), Psikologi Pendidikan, PT. Gramedia, Jakarta.

Packard, Robert G, (2009), Instruction to Education and Teaching. $3^{\text {nd }}$ ed. University of Missouri, USA. 